\title{
HAEMATOLOGICAL AND CARDIORESPIRATORY RESPONSES TO INDUCED HYPERPYREXIA
}

W.W. STOYKA, B.SC., M.D., F.R.C.P.(C) ${ }^{*}$ AND M.B. GARVEY, B.SC., M.D., F.R.C.P.(C) $\dagger$

Elevation of body temperature has been shown to produce altered haematological functions in both man and animals. ${ }^{1,2,3,4}$ Heat stroke and malignant hyperpyrexia are two clinical syndromes which document these disturbances. ${ }^{5,6}$ The syndrome of heat stroke causes haematological changes associated with exertion in an atmosphere of raised effective temperature (E.T.); temperature corrected for humidity and air movement. The syndrome of malignant hyperthermia is an inherited disorder manifesting itself in patients and strains of swine who are exposed to anaesthetic administration. Coagulation disturbances in this syndrome are part of a multisystem disturbance. However, the haematological manifestations of both syndromes are similar. Haemolysis, fibrinolysis, intravascular coagulation, platelet destruction and consequent haemorrhagic diatheses are associated with both these states.,4.6 The purpose of our study was to determine whether similar abnormalities occur in the inactive anaesthetized animal, not susceptible to malignant hyperthermia, under normal humidity where temperature change is the single variable. Associated cardio-respiratory and pertinent metabolic functions were studied to further delineate induced hyperpyrexia from heat stroke and malignant hyperpyrexia.

\section{Methods ANd Procedures}

Forty dogs were induced with thiopentone $5 \mathrm{mgs} / \mathrm{kg}$. The trachea was intubated and anaesthesia was maintained with either penthrane (M.A.C. 1.5 for 20 dogs) or halothane (M.A.C. 1.5 for 20 dogs). A ratio of $2 / 3$ to $1 / 3 \mathrm{~N}_{2} \mathrm{O} / \mathrm{O}_{2}$ was used to supplement the inhalation agent and to provide adequate oxygenation. Preliminary studies in our laboratory revealed M.A.C. 1.5 was essential. Lower concentrations failed to maintain narcosis with increased basal metabolic rates secondary to pyrexia. All animals were allowed to breathe spontaneously and were monitored with an end-tidal infra-red $\mathrm{CO}_{2}$ analyzer to facilitate $\mathrm{PaCO}_{2}$ determinations.

The femoral artery was cannulated for determining systemic arterial pressure, for blood gas analysis and haematology sampling. The femoral vein was cannulated with a Swan Ganz 7F thermodilution cardiac output catheter, the tip of which was placed in the pulmonary artery. This catheter permitted measurement of central venous pressure, of cardiac output by thermodilution, the drawing of mixed venous blood samples and was a route for intravenous infusions. Arterial and mixed venous blood were analyzed with Radiometer electrodes to determine

\footnotetext{
-Assistant Professor, Department of Anaesthesia, University of Toronto, St. Michael's Hospital.

†Assistant Professor, Department of Medicine, University of Toronto, St. Michael's Hospital.
} 
$\mathrm{pH}_{1} \mathrm{PaO}_{2}, \mathrm{PaCO}_{2}$, and arterio-venous oxygen content difference. Haemoglobin, oxygen saturation and carbon monoxide levels were determined with an I.L. Cooximeter. The haematocrit was measured and the mean corpuscular haemoglobin content was calculated. Changes in the oxyhaemoglobin dissociation curve were determined by measuring p50 with an I.L. Co-oximeter. Further blood studies included measurement of serum electrolytes, serum creatine phosphokinase (CPK) and serum lactate levels. These parameters were measured serially at 20 minute intervals throughout the experimental run. In 14 of 40 animals, electromagnetic flow probes, previously placed on the ascending aorta, were used to measure cardiac output by determination of stroke volume for each heart beat. Peripheral resistance was calculated using Green's formula, knowing cardiac output, systemic arterial blood pressure, and central venous pressure.

All animals were wrapped in a K-Thermia heating blanket and the control turned to manual heat. Rectal and oesophageal temperatures were simultaneously monitored with Yeldow Springs tele-thermometers. The rise in animal temperature averaged $6.8^{\circ} \mathrm{C}$ for a 7 hour period $\left(37.2\right.$ to $44.0^{\circ} \mathrm{C}$ or 98.9 to $111.2^{\circ} \mathrm{F}$ ) and produced a 32.5 per cent mortality rate in laboratory animals ( 13 of 40 ).

Specific haematological assessment included coagulation screens for individual factor assay, specific clotting tests, red blood cell survival times, and blood volume studies. Baseline values were obtained after induction of anaesthesia and were compared with values obtained prior to completion of the daily experiment. Red blood cell survival studies were carried out bi-weekly for 21 days. The entire methodology and parameters studied are illustrated in Figure 1.

\section{Results and Discussion}

Serial determinations of haemoglobin, haematocrit, and mean corpuscular haemoglobin content are documented in Figure 2 and plotted against rising temperature. The haemoglobin and haematocrit levels increased while mean corpuscular haemoglobin content stayed constant. Blood volume determinations showed a slow fall. The above changes were indicative of haemoconcentration and not of haemolysis. Other measurements which supported the decision that the observed changes were due to haemoconcentration included normal 21 day red blood cell survival and normal carbon monoxide levels. Carbon monoxide is normally formed as an end product of the catabolism of haemoglobin. According to Coburn et al. ${ }^{7.8}$ carbon monoxide levels are elevated when red blood cells undergo haemolysis or show ineffective erythropoiesis. Stable carbon monoxide levels in our study were definitive evidence that haemolysis was not present.

The actual cause of haemoconcentration in these animals may be the result of the temperature-regulating mechanism which dogs utilize known as thermal panting. In a hot environment poorly sweating or non-sweating dogs lose heat from their respiratory tract by increasing alveolar ventilation in the phenomenon of thermal panting. ${ }^{6}$ The result is increased water vapour loss with subsequent dehydration, haemoconcentration and secondary respiratory alkalosis. This assumption was tested in 6 animals in our study by weighing dogs before and after the experiment. Water vapour accumulation was also determined by weighing 


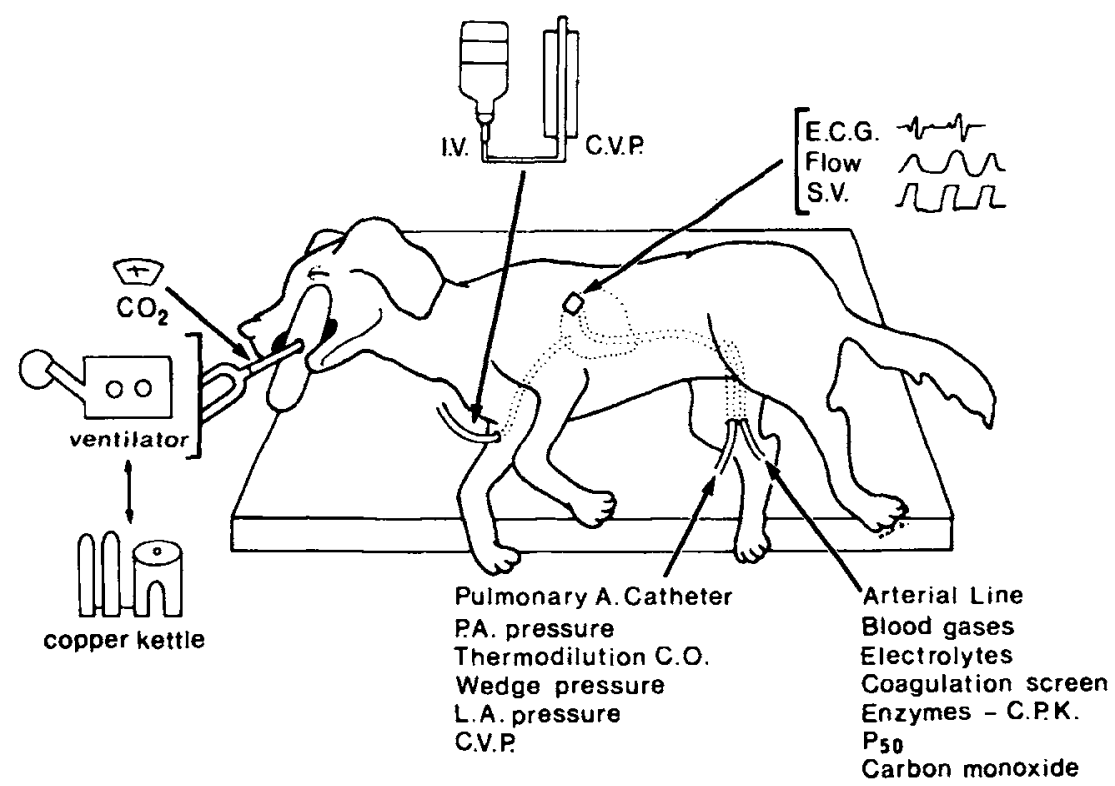

Figure 1. Methodology and the parameters measured in the study.

the soda lime absorber in the circle anaesthetic system. The information obtained in these animals tended partially to confirm haemoconcentration due to thermal panting. The remaining discrepancy may be due to cellular oedema which could be partially assessed by electron microscopy studies of various tissues and organs.

Coagulation disturbances were assessed by the prothrombin time, partial thromboplastin time, thrombin time, and individual factor assay. Prothrombin time, partial thromboplastin time, thrombin time and assays for factors II, V, VII, VIII, IX, X, XI, and XII showed no change from control values after induced hyperpyrexia. Figure 3 documents the results of prothrombin time, partial thromboplastin time and thrombin time determinations while Figures 4 and 5 represent the results of individual factor assays before and after the experiment. These results also rule out any serious depression of fibrinogen levels or the presence of any significant degree of anti-thrombin activity or high levels of fibrin degradation products. The euglobulin lysis time was performed as a measure of plasminogen activation but showed no abnormalities. No disturbances were noted in the platelet count and whole blood clot lysis times remained unchanged throughout the experiment. The end result of all haematological assessment was the complete absence of abnormalities which had been expected to occur with induced hyperpyrexia.

Cardiac function studies were the result of two opposing physiological disturbances. The initial response to the elevation of body temperature was an increase in cardiac output due to increased heart rate, with little change in stroke volume. The increase in cardiac output, peripheral vasodilation and increase in peripheral blood flow was an attempt to dissipate body heat. These results were similar to data obtained by Koroxenidis et al. ${ }^{10}$ in man. However, after $1 \frac{1}{2}$ to 2 hours the secondary response was seen as decreased cardiac output, decreased stroke 


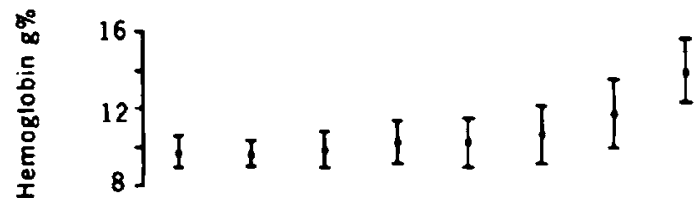

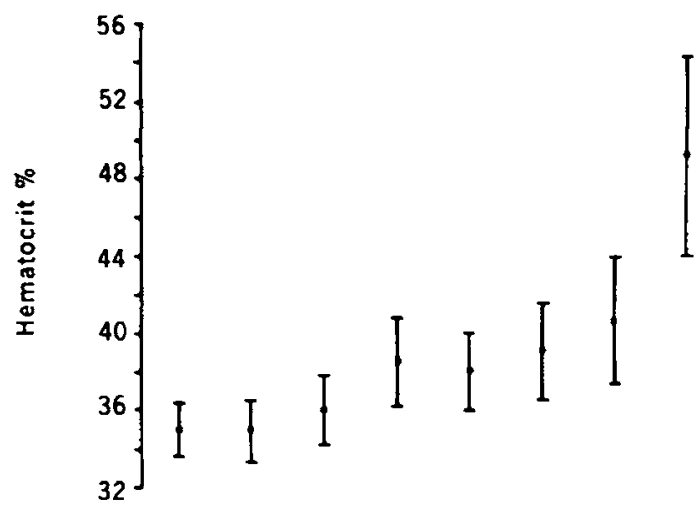

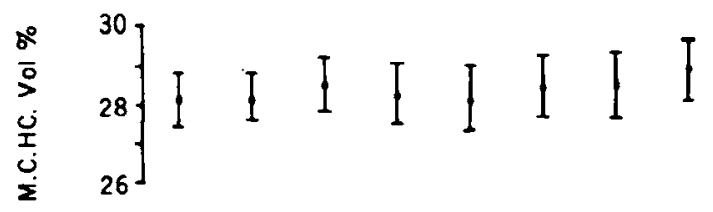

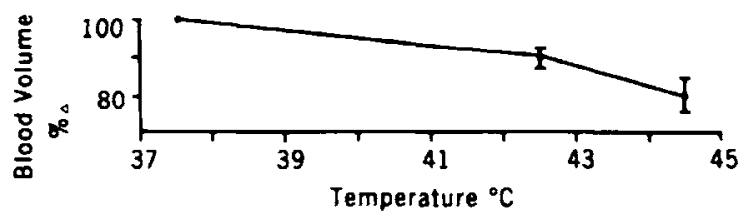

Ficure 2. Haemoglobin, haematocrit, mean corpuscular haemoglobin content and blood volume studies are plotted against the rising temperature. Mean and standard duration values are plotted for 40 animals.

volume, decreased venous return, decreased systemic blood pressure and a significant increase in heart rate. These changes represented a direct response to the blood volume decrease measured by radioactive chromium studies. The cardiovascular results are illustrated in Table I.

Hyperpyrexia created an increased basal metabolic rate with consequent increased oxygen need and increased oxygen utilization. Physiologically, this need was shown in several ways. Peripheral vasodilation and increased peripheral blood flow occurred to make oxygen more readily available to tissues. This was determined by measuring the decrease in peripheral resistance using Green's formula. Cellular respiration revealed a greater utilization of oxygen by the tissues indicated by decreased mixed venous oxygen levels. The result was increased arteriovenous oxygen content differences which were documented with increasing pyrexia.

If adequate oxygen could not be provided to tissue, there would be a necessity for additional energy support systems. Energy would be derived from glycolysis 


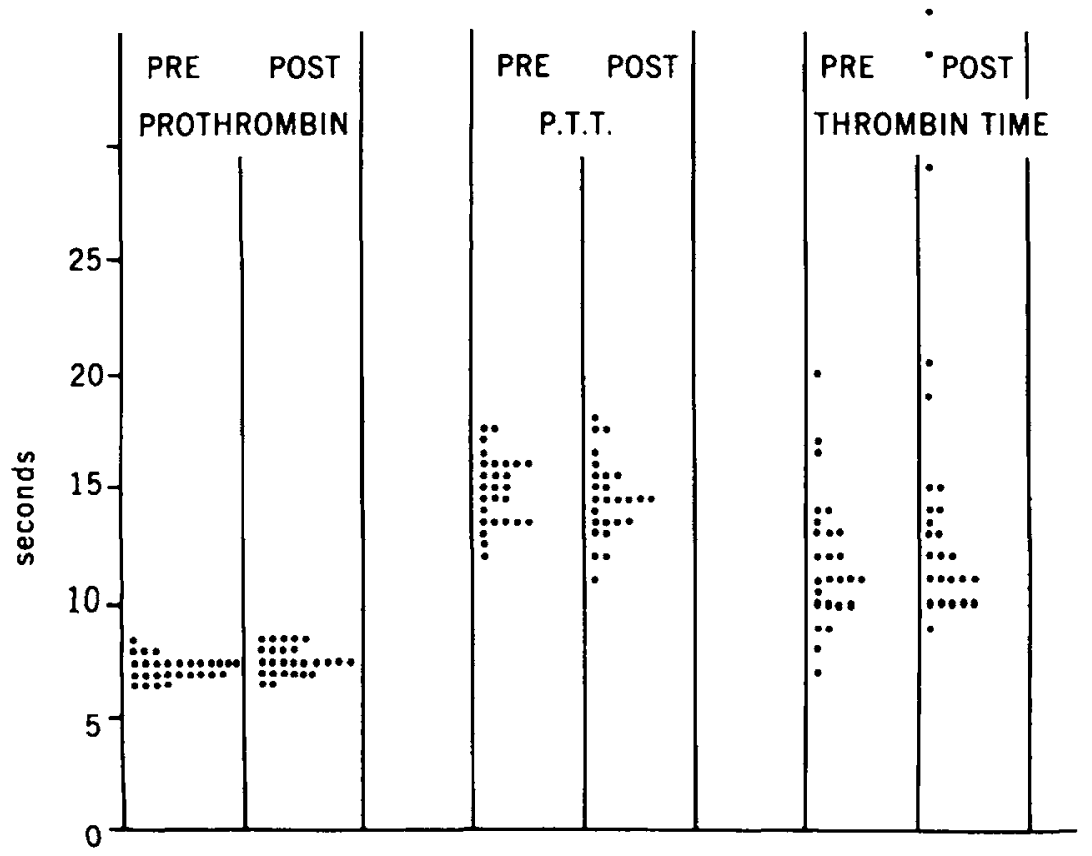

Frgure 3. The results of specific diagnostic clotting tests are documented.

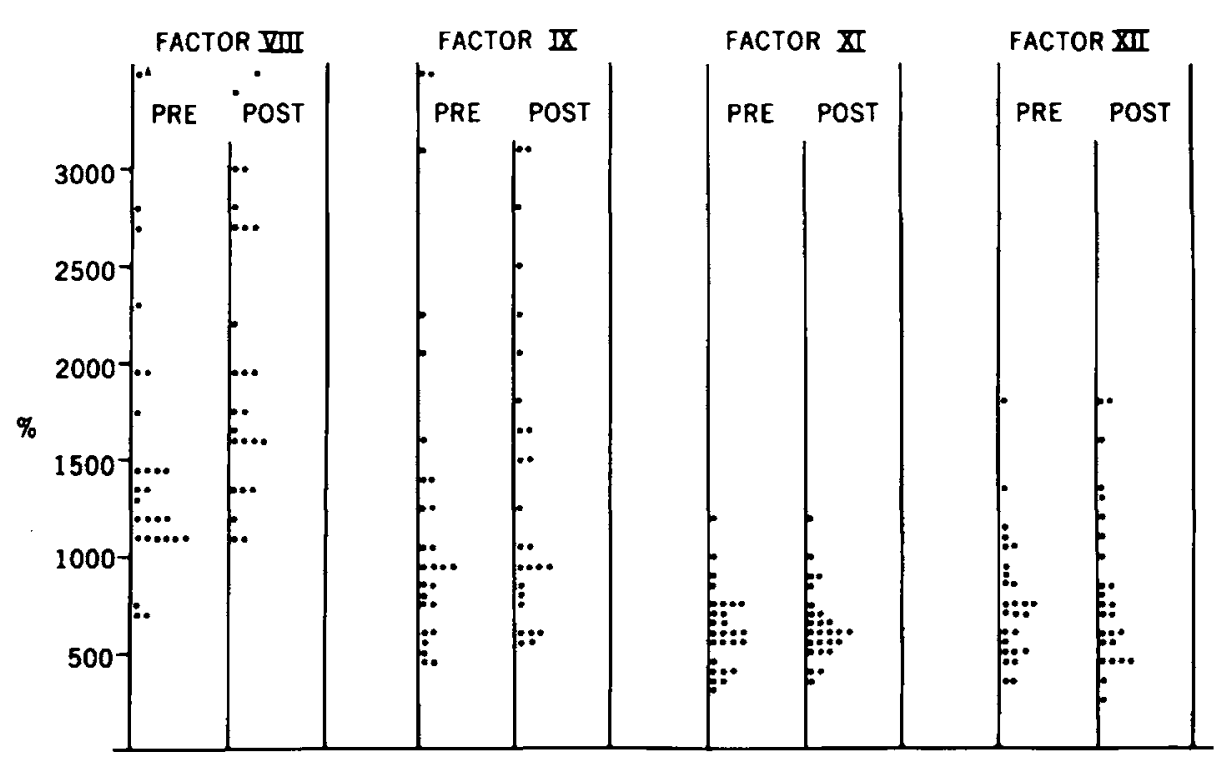

FIGURE 4. Results in the intrinsic serum system for factors VIII, IX, XI, and XII.

or anaerobic metabolism with consequently increased lactate levels, increased base deficits and changes in P50 due to acidotic shift of the oxyhaemoglobin dissociation curve. In this study lactate levels remained stable throughout. In 23 per cent of animals, there was a slight terminal increase in serum lactate. The remaining acid-base changes are presented in Figure 6. The baseline values for dogs showed 


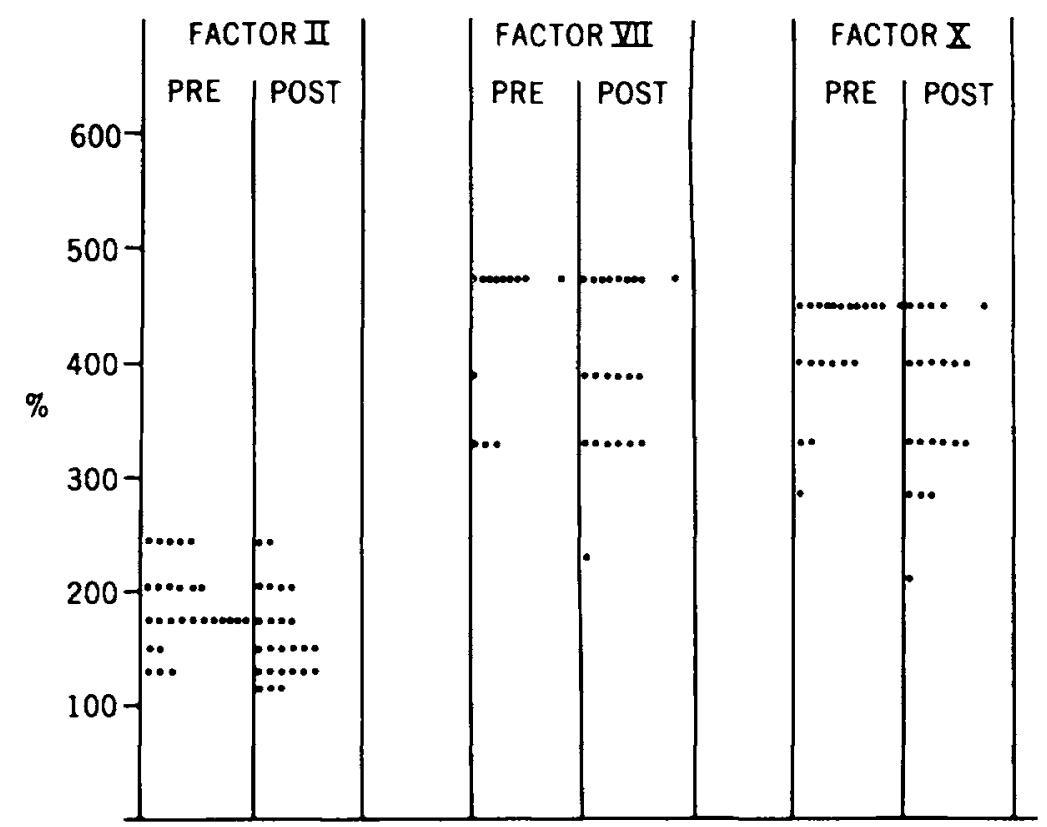

Ficure 5. Results in the extrinsic tissue system for factors II, VII, and X.

TABLE I

The Cardiovascular Response to Hyperpyrexia is shown as a Response to Blood Volume Changes

\begin{tabular}{llll}
\hline Hemodynamic & \multicolumn{2}{c}{ Consequences of Blood Volume Changes in Hyperpyrexia } \\
\hline Decreased & Cardiac & Output & (V..O.) \\
Decreased & Stroke & Volume & (VS.V. 10 $>4)$ \\
Increased & Heart & Rate & (VH.R. 120 250) \\
Decreased & Blood & Pressure & $\left(\right.$ VB.P. $\left.\frac{180}{100}>\frac{80}{60}\right)$ \\
Decreased & Venous & Return & (VC.V.P.) \\
\hline
\end{tabular}

the expected base deficit. These levels did not change until the temperature reached $43^{\circ} \mathrm{C}$ approximately. As temperature rose higher, metabolic acidosis increased. This metabolic change was verified by corresponding changes in P50 on the oxyhaemoglobin dissociation curve. The P50 was a direct measure of the metabolic state, because we had removed temperature factors by correction, found no abnormal haemoglobin variants, measured normal carbon monoxide levels and effectively removed any other factors known to alter the oxyhaemoglobin dissociation curve. One postulated cause for the progressive metabolic acidosis was an increased basal metabolic rate beyond the limit of the metabolic stores as shown by an increasing arterial-venous oxygen content difference. As the tissue extraction increased, the mixed oxygen content fell causing certain organs to find other sources of metabolic energy. Another postulated cause for acidosis was preferential organ perfusion secondary to decreased blood volume, with relative ischaemia of some tissue. 


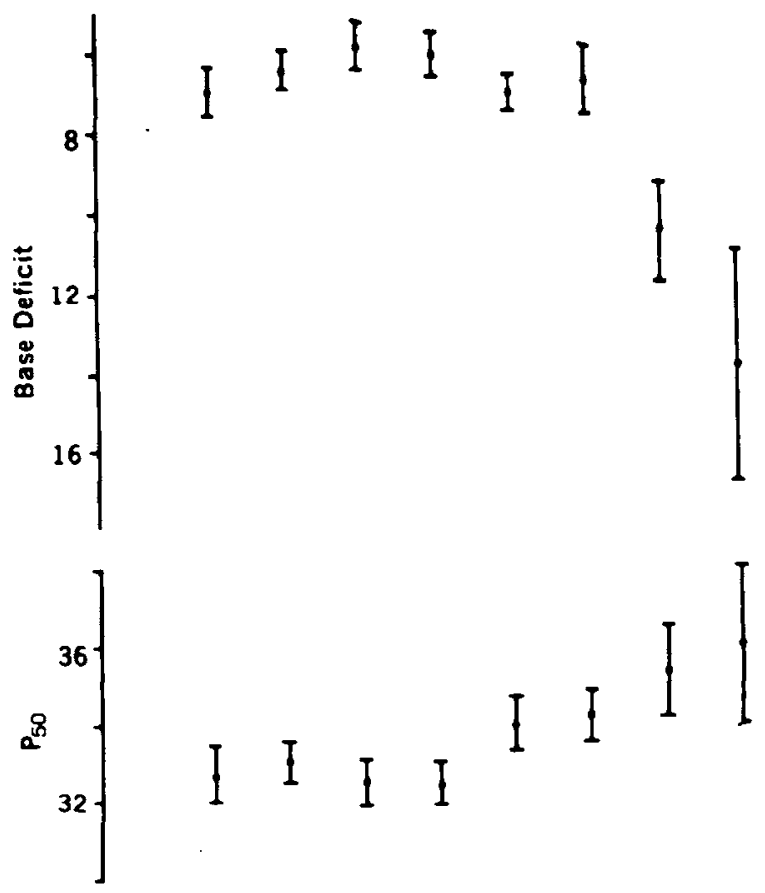

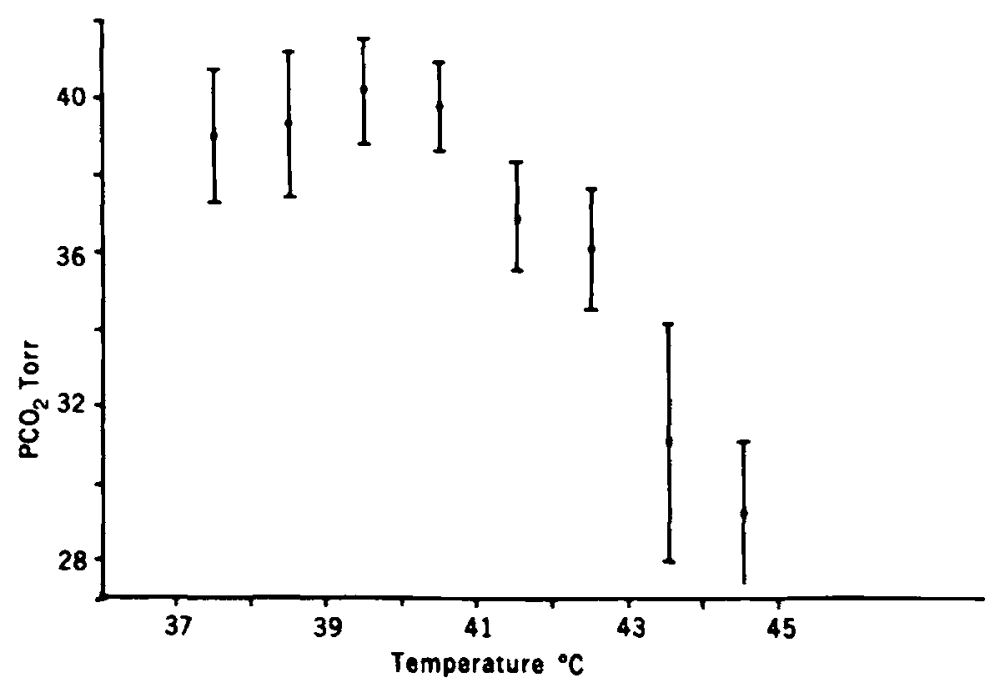

FIGURE 6. The metabolic and respiratory changes associated with hyperpyrexia.

Figure 6 also shows the progressive respiratory alkalosis which occurred in our animals. This was initially due to the mechanism of thermal panting previously described. Terminally, this respiratory alkalosis was a compensation for the progressive metabolic acidosis. The magnitude of hypocapnia did not represent the 200 per cent to 300 per cent increase in respiratory rate, due to the fact that the increased rate was associated with decreased tidal volumes, decreased alveolar 

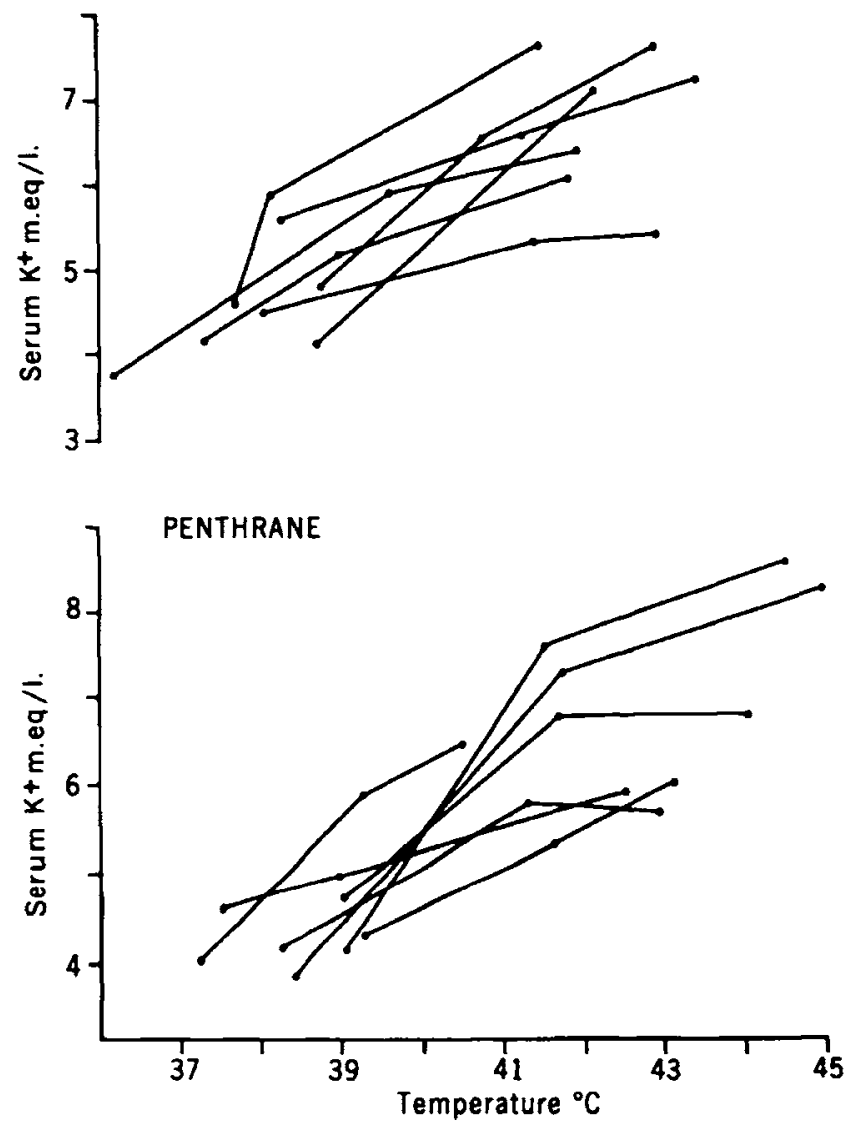

Ficure 7. Serum potassium changes are shown with hyperpyrexia under two anaesthetic agents in 13 animals. The remaining animals showed similar changes but were not plotted.

ventilation and increased dead space ventilation. This was expected when slower rhythmic respiration was replaced by panting in an attempt to release excess body heat.

Arterial oxygen tension $\left(\mathrm{PaO}_{2}\right)$ remained relatively constant throughout our experiment due to several factors. The Haldane effect showed that respiratory alkalosis which decreased carbon dioxide content also enhanced the blood oxygen carrying capacity. The haematocrit increased due to haemoconcentration and possible splenic contraction to increase the oxygen carrying capacity of blood. The increased heart rate and peripheral vasodilation provided a slight decrease in oxygen extraction per unit of blood in the tissues. The use of 66 per cent nitrous oxide and 33 per cent oxygen produced an elevated oxygen level and permitted experimentation on the upper plateau of the oxyhaemoglobin dissociation curve. The absence of hypoxia in our study is in contrast to results obtained by Frankel and co-workers. ${ }^{11}$

Serial determinations of serum electrolytes showed moderate increases for sodium and chloride ions due to haemoconcentration, but no pathological levels were reached. However, serum potassium showed marked increases to pathological levels of 7 to $8 \mathrm{meq} /$ litre. Figure 7 documents the potassium rise with the 
anaesthetic agents halothane and methoxyflurane. These results agreed with the work of Spurr and Barlowe ${ }^{12}$ who showed similar potassium elevations with pyrexia. Serum potassium increases despite the opposing trend for potassium to move into the cells during respiratory alkalosis. The elevation in serum potassium is believed to be due to the effects of hyperpyrexia on liver and gastrointestinal tissue. Another factor is felt to be significant elevation of plasma catecholamines which occurs during pyrexia.

One enzyme measurement warrants special attention in our study. Serum creatine phosphokinase (CPK) was measured, as this enzyme is a valuable screen in the detection of malignant hyperpyrexia. ${ }^{6}$ It is also used as a screening test for injury to skeletal and cardiac muscle. The levels of CPK in our study were normal and remained constant with baseline values despite 6-7 hours of induced hyperpyrexia.

\section{SUMMARY}

Induced hyperpyrexia was compared to malignant hyperpyrexia and heat stroke to determine whether similar abnormalities in haematological function were present. Induced hyperpyrexia showed no evidence of red blood cell haemolysis, no abnormalities in individual clotting factor assay or specific diagnostic clotting tests, no evidence of fibrinolysis or intravascular coagulation and no abnormal platelet count or clot lysis times. These findings are contrary to documented reports on heat stroke and malignant hyperpyrexia and emphasize the fact that induced hyperpyrexia is haematologically dissimilar to heat stroke and malignant hyperpyrexia. The physiological consequences of induced hyperpyrexia were shown as changes due to haemoconcentration and increased oxygen demand. Cardiac function responses were primarily the result of haemoconcentration and decreased blood volume. Acid-base disturbances occurred terminally when temperatures exceeded $43^{\circ} \mathrm{C}\left(107^{\circ} \mathrm{F}\right)$ due to metabolic demands exceeding metabolic stores and preferential organ perfusion causing ischaemia in previously perfused tissues. Associated with these changes was significant hyperkalaemia which proved to be the cause of death in several experimental animals.

The documented results in this study enable one to conclude that induced hyperpyrexia is relatively harmless haematologically and that it can be readily treated with adequate fluid replacement, buffer infusion as required and a method of cooling to quickly return body temperatures to normal. The results also indicate the necessity for temperature monitoring as the most effective therapeutic tool.

\section{RÉSUMÉ}

Les auteurs ont comparé l'hyperpyrexie délibérée à l'hyperpyrexie maligne et au coup de chaleur pour déterminer si des anomalies comparables survenaient au niveau de la fonction hématologique. L'hyperpyrexie délibérée ne montrait aucune évidence d'hémolyse des globules rouges, aucune anomalie dans le titrage du facteur de coagulation individuel ou dans les épreuves de diagnostic spécifique de la coagulation, aucune évidence de fibrinolyse ou de coagulation intra-vasculaire, ni aucune anomalie dans la numération des plaquettes ou dans la vitesse de lyse du caillot. Ces constatations sont à l'encontre des rapports documentés sur le coup 
de chaleur et sur l'hyperpyrerie maligne, et soulignent le fait que l'hyperpyrexie délibérée est hématologiquement différente du coup de chaleur et de l'hyperpyrexie maligne. Les conséquences physiologiques de l'hyperpyrexie délibérée furent démontrées comme étant des changements résultant de l'hémoconcentration et de la demande accrue en oxygène. Les réponses de la fonction cardiaque étaient essentiellement la conséquence d'une hémoconcentration et d'une diminution du volume sanguin. Les troubles de l'équilibre acido-basique survenaient à la phase terminale lorsque les températures excédaient $43^{\circ} \mathrm{C}$. $\left(107^{\circ} \mathrm{F}\right.$.) du fait que les demandes métaboliques excédaient les réserves et par suite d'une perfusion préférentielle des organes qui conduisait à une ischémie dans des tissus jusque-là perfusés. On notait, associée à ces modifications, une hyperkaliémie significative qui s'avérait la cause de mort dans nombre d'animaux d'expérimentation.

Les résultats documentés apparaissant dans cette étude permettent de conclure que l'hyperpyrexie délibérée est relativement inoffensive du point de vue histologique et qu'elle peut être traitée promptement par un remplacement liquidien approprié, par l'infusion de substance-tampon selon les besoins, et par une méthode de refroidissement qui permette de ramener vers la normale les températures corporelles. Les résultats indiquent aussi la nécessité de moniteurs à température comme l'instrument thérapeutique le plus efficace.

\section{ACKNOWLEDGMENTS}

The authors wish to acknowledge the technical assistance of the Anaesthesia Research Laboratory; St. Michael's Hospital, under the direction of Mr. Colin Kay. This research project was supported by the St. Michrel's Hospital Research Society and the Ontario Heart Foundation which made thermodilation cardiac output available for research purposes.

\section{REFERENCES}

1. Rosenthal, T., Shapiro, Y., Seligsohn, U., \& Ramot, B. Disseminated intravascular coagulation in experimental heatstroke. Thromb. Diath. Hemorh. Vol. 26; \#3; pg. $417-425$ ( 1971 ).

2. Myerstein, N. \& Cassuto, Y. Hematological changes in heat acclimated golden hamsters. Brit. J. Haematol. Vol. 18; pg. 417-423 (1970),

3. Stefanini, M. \& Spicer, D. Hemostolic breakdown, fibrinoylsis and acquired hemolytic anemia in a patient with fatal heatstroke. Amer. J. Clin. Path. 55: 180-186 (1971).

4. WEBER, M.B. \& BLAKELY, J.A. The haemorrhagic diathesis of heatstroke. Lancet Vol, 1 , pg. 1190-1192 (June 14, 1969).

5. Shibolet, S., Coll, R., Gilat, T., \& Sohar, E. Heatstroke: Its clinical picture and mechanism in 36 cases. Quarterly J. Med. No. 144, pg. 525-548 (Oct. 1967).

6. Britr, B.A. \& Kalow, W. Malignant hyperthermia: A statistical review. Canad. Anaesth. Soc. J. Vol, 17; \#4; pg. 293-315 (July, 1970).

7. Coburn, R.F. Endogenous carbon monoxide production. N.E.J.M. Vol. 282, No. 4, pg. 207-209 (Jan. 1970).

8. Coburn, R.F., Williams, W.J., Whate, P., \& Kahn, S.B. The production of carbon monoxide from hemoglobin in vivo. J. Clin. Invest. Vol. 46, No. 3, pg. 346-356 (1967).

9. Hicgins, E.A. \& IAMPiETro, P.F. Thermal panting and the initiation of respiratory alkalosis. Canad. J. Physiol. and Pharmacol. Vol. 45, \#1, pg. 1-12 (Jan. 1967).

10. Koroxenidis, G.T., Shepherd, J.T., \& Marshald, R.J. Cardiovascular response to acute heat stress. J. Appl. Physiol. Vol. 16, \#5; pg. 869-872 (1961).

11. Frankel, H.M., Ellis, JR., J.P., \& Cain, S.M. Development of tissue hypoxia during progressive hyperthermia in dogs. An. J. Physiol. 205 (4), pg. 733-737 (1963).

12. Spurr, G.B. \& Barlow, G. Tissue electrolytes in hyperthermic dogs. J. Appl. Physiol. Vol. 28 , No. 1, pg. 13-17 (1970). 